\author{
А. А. Крючин, Н. В. Солоніна, Н. М. Мініна, А. Н. Овсієнко \\ Інститут проблем реєстрації інформації НАН України \\ вул. М. Шпака, 2, 03113 Київ, Україна
}

\title{
Аослідження динаміки публікацій з інформатики в реферативній базі даних «Україніка наукова»
}

Наведено оцінку інноваційного потенцііалу наукових досліджень учених України в галузі інформатики з використанням бази даних «Наукова періодика України» та реферативної бази даних «Україніка наукова».

Ключові слова: публікачійна активність, реферативна база даних, наукометричні дослідження, інформаційні технології.

\section{Вступ}

Створення ефективних систем моніторингу та прогнозування розвитку наукових галузей є одним з актуальних завдань для пошуку і вибору нових перспективних технологій $[1,2]$. Особливо важливо при цьому проведення прогнозноаналітичних досліджень у галузях, які динамічно розвиваються. Одним із таких напрямків $\epsilon$ інформаційні технології (IT).

Визнаним методом прогнозування напрямків розвитку науково-технічних галузей є аналіз публікацій активності $[3,4]$. У сучасному світі спостерігається швидке зростання загальної кількості наукових публікацій, у першу чергу, в країнах з високими та стабільними темпами економічного зростання.

Створені бази даних широко застосовуються для оперативного виявлення новітніх напрямків досліджень і перспективних розробок.

Крім вирішення головного завдання, яке ставилося при створенні баз даних реферативної інформації і виданні реферативних журналів, — ознайомлення науково-технічних спеціалістів з результатами останніх розробок і досліджень, джерела реферативної інформації все ширше використовуються для проведення наукометричних досліджень. Ці дослідження спрямовані на пошук нових перспективних науково-технічних напрямків («гарячих точок»), дослідження географічного розміщення центрів наукової активності, встановлення взаємозв'язків і взаємодії наукових шкіл, дослідження кореляції публікаційної активності із захистом дисертацій та отриманням патентів. Наукометричні дослідження з використанням реферативних баз даних широко проводяться у США, Німеччині, Росії. Для підви- 
щення точності прогнозування на основі даних публікаційної активності вони доповнюються і порівнюються з результатами вебометричного аналізу. Більш точному визначенню тенденцій динамічного зростання обсягів досліджень за певними науково-технічними напрямками сприяє порівняльний аналіз кількості наукових публікацій і захищених дисертацій [5].

Мета роботи полягала у відпрацюванні технології проведення наукометричних досліджень на основі баз даних «Наукова періодика» та українського реферативного журналу «Джерело» («Україніка наукова»). Дослідження базувалися на аналізі публікаційної активності. Наукометричні дослідження проводились у галузі інформаційних технологій.

\section{Сучасний стан наукових періодичних виАань у галузі інформаційних технологій}

Тривалий час загальновизнаною формою представлення результатів наукових досліджень, технологічних розробок були публікації статей у наукових журналах. У світі щорічно видається сотні тисяч статей з проблем інформатики та комп'ютерної техніки. Кількість наукових публікацій, їхній розподіл за певними напрямками досліджень безумовно $є$ індикатором оцінки науково-технічного потенціалу країни. Так, у США видається понад 500 тис. наукових статей у рік, у Росії близько 250 тис. [6]. Щорічна кількість статей, що публікують учені НАН України, за останні 10 років збільшилася з 17,7 до 25,9 тис., п'ята частина 3 яких зазвичай виходить у зарубіжних періодичних виданнях [7]. У системі наукових комунікацій періодичні видання, що складають близько дві третини документного інформаційного потоку, забезпечують цілий ряд функцій, без яких неможливий розвиток науки: передачу і застосування наукових знань, професійне спілкування та взаємодію науковців. Наукові видання, які здійснюють свій внесок у системи контролю достовірності і якості публікованих матеріалів, відіграють важливу роль у підвищенні ефективності вітчизняної науки.

Аналіз публікаційної активності в певній галузі знань надає важливу інформацію про розвиток науки, наукові школи, а також зв'язки між ними. Одним із пріоритетних напрямків вважають дослідження і розробки в галузі інформаційних технологій. Відображенням цього є постійно зростаюча кількість публікацій у періодиці. В Україні друкується близько 130 фахових журналів, збірників та іншої літератури в галузі інформаційних технологій та комп'ютерної техніки. Більшість журналів повністю присвячено різним напрямкам IT, а деякі (в основному наукові праці вищих навчальних закладів) представляють результати досліджень у різних галузях техніки.

Кількість українських наукових періодичних видань, в яких публікуються статті з інформатики постійно зростає. За останні 12 років засновано 45 нових видань. Це близько 35 \% від загальної кількості видань у цій галузі. Однак слід зазначити, що в деяких виданнях кількість статей з цього напрямку не перевищує двох-трьох, що призводить до суттєвого розсіяння публікацій.

Аналіз публікаційної активності в галузі інформаційних технологій проведено за напрямками, що визначено Постановою Кабінету міністрів України № 942 від 07.09.2011 р. як пріоритетні (табл. 1): 
Таблиця 1. Пріоритетні напрями розвитку в галузі інформаційних технологій

\begin{tabular}{c|l}
\hline \hline №o & \multicolumn{1}{|c}{ Напрямок } \\
\hline \hline I & $\begin{array}{l}\text { Нові апаратні рішення для перспективних засобів обчислювальної техніки, інформа- } \\
\text { ційних і комунікаційних технологій }\end{array}$ \\
\hline II & $\begin{array}{l}\text { Інтелектуальні інформаційні та інформаційно-аналітичні технології. Інтегровані сис- } \\
\text { теми баз даних і знань. Національні інформаційні ресурси }\end{array}$ \\
\hline III & $\begin{array}{l}\text { Суперкомп’ютерні програмно-технічні засоби, телекомунікаційні мережі і системи. } \\
\text { Грід- і клауд-технології }\end{array}$ \\
\hline IV & Технології і засоби розробки програмних продуктів і систем \\
\hline V & $\begin{array}{l}\text { Технології і засоби математичного моделювання, оптимізації і системного аналізу } \\
\text { розв’язання надскладних завдань державного значення }\end{array}$ \\
\hline VI & $\begin{array}{l}\text { Технології й інструментальні засоби електронного урядування. Інформаційно-аналі- } \\
\text { тичні системи, системи підтримки прийняття рішень. Ситуаційні центри }\end{array}$ \\
\hline VII & Технології і засоби захисту інформації \\
\hline \hline
\end{tabular}

На рис. 1 наведено розподіл журналів за напрямами в галузі IT (у відсотках до загальної кількості видань з інформатики), в тому числі видань, заснованих за останні 12 років.

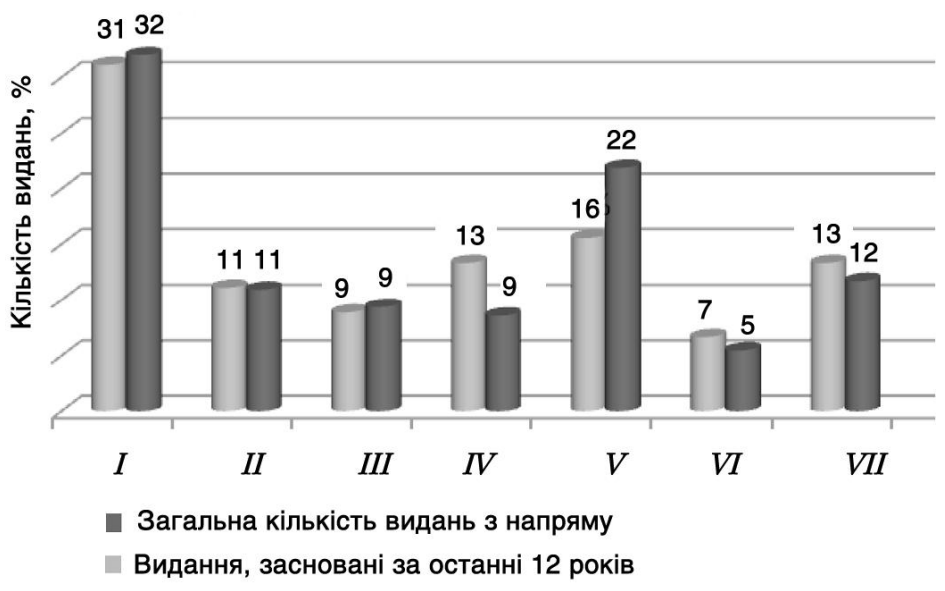

Рис. 1. Розподіл журналів у галузі інформаційних технологій за пріоритетними напрямками наукових досліджень

3 огляду на величезні обсяги нової інформації, необхідність їі швидкого розповсюдження і обговорення опублікованих робіт, форма представлення наукових публікацій швидко змінюється, віддаючи перевагу електронним виданням. Набувають розвитку міжнародні системи електронної публікації наукових робіт $[8,9]$.

Зростає присутність вітчизняних академічних наукових журналів у міжнародних базах даних: EBSCO, Scopus, PubMed, BIOSIS тощо та у переліку ISI Tomson Reuters. До останнього, наприклад, 2010 року внесено журнал «Проблемы управления и информатики» [7].

У базі даних Scopus на 1996-2012 роки представлено 2450 наукових публікацій українських учених у галузі інформатики та комп'ютерної техніки, що стано- 
вить близько 2,22 \% від загальної кількості публікацій у цьому науковому напрямку. Для порівняння: публікації у галузі матеріалознавства становлять 11 \%, фізики - 10 \%. Українські автори не часто посилаються на власні роботи (показник самоцитування 1,88) [8].

У базі даних «Наукова періодика України» Національної бібліотеки України імені В.І. Вернадського представлені у відкритому доступі 1802 фахові періодичні видання. Кількість щоденних звернень до цієї бази даних перевищує 300 тисяч [11]. Наукові видання за напрямками IT складають приблизно 7 \% від загальної кількості наукових фахових видань, що представлені у цій базі (рис. 2).

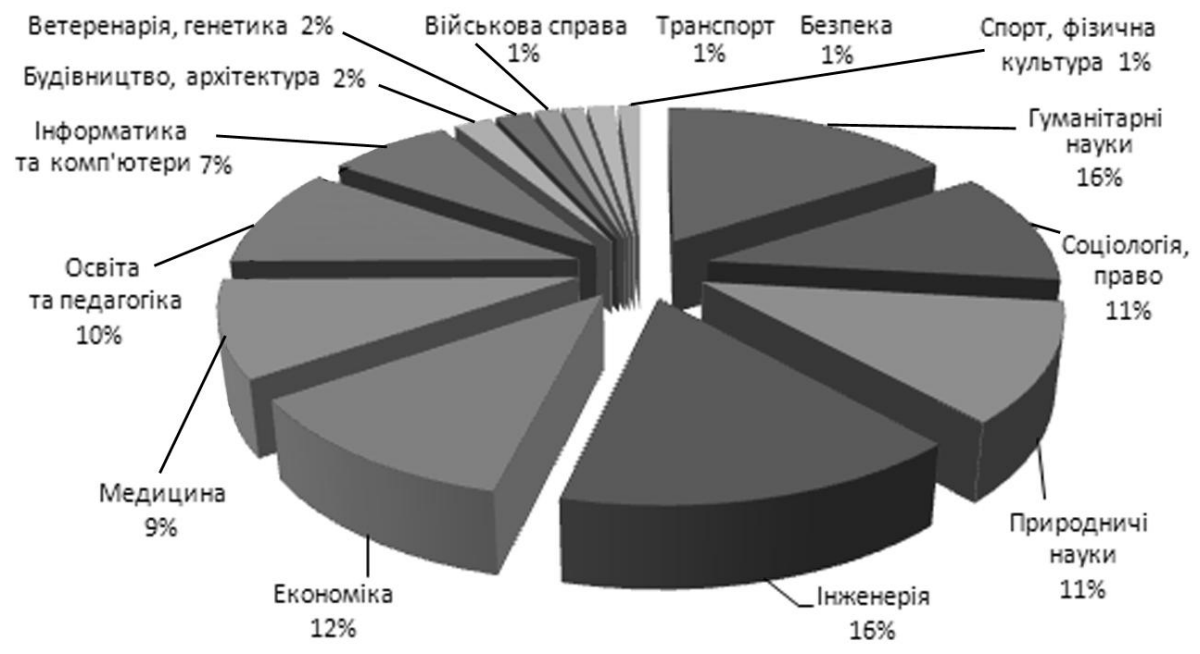

Рис. 2. Розподіл наукових публікацій за галузевими дослідженнями

У табл. 2 наведено перелік журналів, до повнотекстових версій яких най частіше звертаються читачі. Мала кількість звернень до деяких видань може бути пов'язана з відсутністю останніх номерів журналів у базі даних «Наукова періодика України».

Слід зазначити, що відсоток звернень до наукових публікацій у галузі інформаційних технологій складає близько 9 \% (8,91 \%) і перевищує відсоток публікацій у цій галузі знань.

Таблиця 2. Наукові журнали України в галузі IT, до повнотекстових версій яких найбільш часто звертаються читачі

\begin{tabular}{|c|c|c|c|}
\hline Назва журналу & $\begin{array}{c}\text { Засновник, } \\
\text { рік заснування }\end{array}$ & Тематика * & $\begin{array}{c}\text { Кількість звер- } \\
\text { нень (\%***) } \\
\text { у } 2012 \text { р. } \\
\end{array}$ \\
\hline Наукові записки НАУКМа & $\begin{array}{l}\text { Національний університет } \\
\text { «Києво-Могилянська акаде- } \\
\text { мія», } 1996 .\end{array}$ & $\begin{array}{l}\text { Комп’ютерні } \\
\text { науки (III) }\end{array}$ & $\begin{array}{l}49118 \\
(1,4 \%)\end{array}$ \\
\hline $\begin{array}{l}\text { Вісник Національного } \\
\text { університету «Львівська } \\
\text { політехніка» }\end{array}$ & 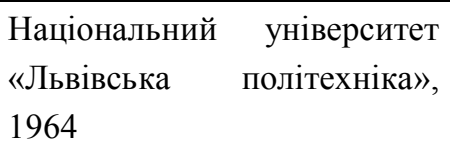 & $\begin{array}{l}\text { Автоматика, } \\
\text { вимірювання та } \\
\text { керування (IV) }\end{array}$ & $\begin{array}{c}41851 \\
(1,21 \%)\end{array}$ \\
\hline
\end{tabular}




\begin{tabular}{|c|c|c|c|}
\hline \multicolumn{4}{|c|}{ Продовження табл. 1} \\
\hline $\begin{array}{l}\text { Вісник Харківського. на- } \\
\text { ціонального університету }\end{array}$ & $\begin{array}{l}\text { Харківський національний } \\
\text { університет імені В.Н. Кара- } \\
\text { зіна, } 2008\end{array}$ & $\begin{array}{l}\text { Радіофізика та } \\
\text { електроніка (I) }\end{array}$ & $\begin{array}{c}32793 \\
(1,18 \%)\end{array}$ \\
\hline $\begin{array}{l}\text { Вісник Національного } \\
\text { технічного університету } \\
\text { «Харківський політехніч- } \\
\text { ний інститут» }\end{array}$ & $\begin{array}{lr}\text { Національний } & \text { технічний } \\
\text { університет } & \text { «Харківський } \\
\text { політехнічний } & \text { інститут», } \\
2001 & \\
\end{array}$ & $\begin{array}{l}\text { Інформатика i } \\
\text { моделювання (II) }\end{array}$ & $\begin{array}{c}23646 \\
(0,85 \%)\end{array}$ \\
\hline $\begin{array}{l}\text { Вісник Запорізького наці- } \\
\text { онального університету }\end{array}$ & $\begin{array}{l}\text { Запорізький } \text { національний } \\
\text { університет, } 1997\end{array}$ & $\begin{array}{l}\text { Фізико-матема- } \\
\text { тичні науки (II) }\end{array}$ & $\begin{array}{c}19421 \\
(0,58 \%) \\
\end{array}$ \\
\hline $\begin{array}{l}\text { Праці Одеського політех- } \\
\text { нічного університету }\end{array}$ & $\begin{array}{l}\text { Одеський національний по- } \\
\text { літехнічний } \quad \text { університет, } \\
1996\end{array}$ & Технічні науки (I) & $\begin{array}{c}19147 \\
(0,55 \%)\end{array}$ \\
\hline $\begin{array}{l}\text { Системи обробки } \\
\text { інформації }\end{array}$ & $\begin{array}{l}\text { Харківський } \quad \text { університет } \\
\text { Повітряних Сил імені I. Ко- } \\
\text { жедуба, } 1996\end{array}$ & $\begin{array}{l}\text { Технічні науки } \\
\text { (V) }\end{array}$ & $\begin{array}{c}13792 \\
(0,45 \%)\end{array}$ \\
\hline $\begin{array}{l}\text { Наукові праці. Сер. } \\
\text { Комп’ютерні технології }\end{array}$ & $\begin{array}{l}\text { Чорноморський державний } \\
\text { університет імені Петра Мо- } \\
\text { гили, } 1997\end{array}$ & $\begin{array}{l}\text { Інтелектуальні } \\
\text { системи і техно- } \\
\text { логії (II) } \\
\end{array}$ & $\begin{array}{c}11963 \\
(0,37 \%)\end{array}$ \\
\hline Вісник СевНТУ & $\begin{array}{l}\text { Севастопольський націона- } \\
\text { льний технічний універси- } \\
\text { тет, } 1995\end{array}$ & $\begin{array}{l}\text { Інформатика. } \\
\text { Електроніка. } \\
\text { Зв’язок (I) }\end{array}$ & $\begin{array}{c}11639 \\
(0,36 \%)\end{array}$ \\
\hline $\begin{array}{l}\text { Електротехнічні та } \\
\text { комп'ютерні системи }\end{array}$ & $\begin{array}{l}\text { Одеський національний по- } \\
\text { літехнічний } \quad \text { університет, } \\
1965\end{array}$ & $\begin{array}{l}\text { Комп’ютерні сис- } \\
\text { теми (III) }\end{array}$ & $\begin{array}{c}10529 \\
(0,34 \%)\end{array}$ \\
\hline Вісник Книжкової палати & $\begin{array}{l}\text { Книжкова палата України } \\
\text { імені Івана Федорова, } 1996\end{array}$ & $\begin{array}{l}\text { Технічні науки } \\
\text { (II) }\end{array}$ & $\begin{array}{c}9634 \\
(0,30 \%) \\
\end{array}$ \\
\hline Доповіді НАН України & $\begin{array}{l}\text { Президія Національної ака- } \\
\text { демії наук України, } 1939\end{array}$ & Технічні науки (I) & $\begin{array}{c}8992 \\
(0,30 \%)\end{array}$ \\
\hline
\end{tabular}

Примітка: * - у дужках зазначено напрямок у галузі інформатики (див. табл. 1).

** — відсоток загальної кількості звернень до БД.

Частково вирішенню проблеми донесення до широкої наукової громадськості інформації, представленої у наукових журналах, сприяє видання реферативних журналів, формування баз даних реферативної інформації. Український реферативний журнал «Джерело» містить дані про понад 700 періодичних видань, у тому числі в 270 журналах зафіксовано публікації у галузі інформаційних технологій. При цьому переважна кількість публікацій (67 \%) сконцентрована в профільних журналах, решта - у загальнотехнічних, природничо-наукових, соціально-економічних і гуманітарних. Перелік журналів, статті з яких реферуються в журналі «Джерело» постійно збільшується.

У наукових журналах інститутів відділення інформатики НАН України (табл. 3) результати своїх досліджень за останні 3 роки опублікували понад 1050 авторів - це відомі вчені, аспіранти та фахівці в галузі інформаційних технологій, кібернетики та комп'ютерної техніки. Близько 52 \% авторів - учені з науковими сту- 
пенями кандидата та доктора наук з різних галузей, які мають праці також у галузі інформатики. 41 \% авторів - це наукові співробітники та інженерні працівники, $7 \%$ - аспіранти.

Таблиця 3. Наукові журнали інститутів відділення інформатики НАН України, до повнотекстових версій яких найбільш часто звертаються читачі

\begin{tabular}{|c|c|c|c|}
\hline $\begin{array}{c}\text { Назва журналу, } \\
\text { рік заснування } \\
\text { (тематичний } \\
\text { напрямок*) } \\
\end{array}$ & Засновник & Головний редактор & $\begin{array}{c}\text { Кількість } \\
\text { звернень } \\
(\% * *) \\
\text { у } 2012 \text { р. } \\
\end{array}$ \\
\hline $\begin{array}{l}\text { Искусственный } \\
\text { интеллект, } 1996 \text { (II) }\end{array}$ & $\begin{array}{l}\text { Інститут проблем штучного } \\
\text { інтелекту МОН України та } \\
\text { НАН України }\end{array}$ & $\begin{array}{l}\text { Шевченко Анатолій } \\
\text { Іванович }\end{array}$ & $\begin{array}{c}4091 \\
(0,12 \%)\end{array}$ \\
\hline $\begin{array}{l}\text { Реєстрація, зберігання і } \\
\text { обробка даних, } 1998 \\
\text { (I, VI, VII) }\end{array}$ & $\begin{array}{l}\text { Інститут проблем реєстрації } \\
\text { інформації НАН України }\end{array}$ & $\begin{array}{l}\text { Петров Вячеслав } \\
\text { Васильович }\end{array}$ & $\begin{array}{c}3264 \\
(0,10 \%)\end{array}$ \\
\hline $\begin{array}{l}\text { Математичні машини і } \\
\text { системи, } 1994 \text { (I, IV) }\end{array}$ & $\begin{array}{l}\text { Інститут проблем математич- } \\
\text { них машин і систем НАН } \\
\text { України }\end{array}$ & $\begin{array}{l}\text { Морозов Анатолій } \\
\text { Олексійович }\end{array}$ & $\begin{array}{c}1717 \\
(0,05 \%)\end{array}$ \\
\hline $\begin{array}{l}\text { Комп’ютерні засоби, } \\
\text { мережі та системи, } 2002 \\
\text { (IV) }\end{array}$ & $\begin{array}{l}\text { Інститут кібернетики імені } \\
\text { В.М. Глушкова }\end{array}$ & $\begin{array}{l}\text { Палагін Олександр } \\
\text { Васильович }\end{array}$ & $\begin{array}{c}1403 \\
(0,04 \%)\end{array}$ \\
\hline $\begin{array}{l}\text { Проблеми програмував- } \\
\text { ня, } 1999 \text { (II, VI) }\end{array}$ & $\begin{array}{l}\text { Інститут програмних систем } \\
\text { НАН України }\end{array}$ & $\begin{array}{l}\text { Андон Пилип } \\
\text { Іларіонович (200) }\end{array}$ & $\begin{array}{c}1202 \\
(0,04 \%)\end{array}$ \\
\hline $\begin{array}{l}\text { Економіко-математичне } \\
\text { моделювання соціально- } \\
\text { економічних систем, } \\
2001(\mathrm{~V}) \\
\end{array}$ & $\begin{array}{l}\text { Міжнародний } \\
\text { навчальний центр інфово- } \\
\text { ційних технологій та систем } \\
\text { НАН і МОН України } \\
\end{array}$ & $\begin{array}{l}\text { Гриценко Володимир } \\
\text { Ілліч }\end{array}$ & $\begin{array}{c}937 \\
(0,03 \%)\end{array}$ \\
\hline $\begin{array}{l}\text { Теорія оптимальних } \\
\text { рішень, } 1967 \text { (VI) }\end{array}$ & $\begin{array}{l}\text { Інститут кібернетики імені } \\
\text { В.М. Глушкова НАН України }\end{array}$ & $\begin{array}{l}\text { Кривонос Юрій } \\
\text { Георгійович }\end{array}$ & $\begin{array}{c}555 \\
(0,02 \%)\end{array}$ \\
\hline $\begin{array}{l}\text { Проблемы управления и } \\
\text { информатики, } 1956 \\
\text { (V) }\end{array}$ & $\begin{array}{l}\text { Інститут кібернетики імені } \\
\text { В.М. Глушкова НАН України, } \\
\text { Інститут космічних дослід- } \\
\text { жень НАН України }\end{array}$ & $\begin{array}{l}\text { Кунцевич Всеволод } \\
\text { Михайлович }\end{array}$ & $\begin{array}{c}518 \\
(0,02 \%)\end{array}$ \\
\hline $\begin{array}{l}\text { Управляющие системы } \\
\text { и машины, } 1972 \\
\text { (I, VII) }\end{array}$ & $\begin{array}{l}\text { Міжнародний науково-нав- } \\
\text { чальний центр інформаційних } \\
\text { технологій та систем, Інститут } \\
\text { кібернетики ім. В.М. Глушко- } \\
\text { ва НАН України }\end{array}$ & $\begin{array}{l}\text { Гриценко Володимир } \\
\text { Ілліч }\end{array}$ & $\begin{array}{c}358 \\
(0,01 \%)\end{array}$ \\
\hline $\begin{array}{l}\text { Компьютерная матема- } \\
\text { тика, } 2000(\mathrm{~V})\end{array}$ & $\begin{array}{l}\text { Інститут кібернетики імені } \\
\text { В.М. Глушкова НАН України }\end{array}$ & $\begin{array}{l}\text { Сергієнко Іван } \\
\text { Васильович }\end{array}$ & $\begin{array}{c}305 \\
(0,01 \%)\end{array}$ \\
\hline $\begin{array}{l}\text { Системні дослідження } \\
\text { та інформаційні техно- } \\
\text { логіï, } 2001 \text { (I, VI) }\end{array}$ & $\begin{array}{l}\text { «Інститут прикладного систе- } \\
\text { много аналізу» НТУУ «КПІ» } \\
\text { МОН та НАН України }\end{array}$ & $\begin{array}{l}\text { Згуровський } \\
\text { Михайло Захарович }\end{array}$ & $\begin{array}{c}291 \\
(0,01 \%)\end{array}$ \\
\hline
\end{tabular}




\begin{tabular}{|c|c|c|c|}
\hline \multicolumn{4}{|c|}{ Продовження табл. 2} \\
\hline $\begin{array}{l}\text { Індуктивне моделюван- } \\
\text { ня складних систем, } \\
2009 \text { (V) }\end{array}$ & $\begin{array}{l}\text { Міжнародний } \\
\text { навчальний центр інфово- } \\
\text { ційних технологій та систем } \\
\text { НАН та МОН України, }\end{array}$ & $\begin{array}{l}\text { Степашко Володимир } \\
\text { Семенович }\end{array}$ & $\begin{array}{c}282 \\
(0,01 \%)\end{array}$ \\
\hline $\begin{array}{l}\text { Кибернетика и систем- } \\
\text { ный анализ, } 1965 \text { (V) }\end{array}$ & $\begin{array}{l}\text { Інститут кібернетики ім. В.М. } \\
\text { Глушкова НАН України }\end{array}$ & $\begin{array}{l}\text { Сергієнко Іван } \\
\text { Васильович }\end{array}$ & $\begin{array}{c}250 \\
(0,01 \%)\end{array}$ \\
\hline $\begin{array}{l}\text { Кибернетика и вычис- } \\
\text { лительная техника, } 1965 \\
\text { (I) }\end{array}$ & $\begin{array}{l}\text { Міжнародний } \\
\text { навчальний центр інформа- } \\
\text { ційних технологій та систем } \\
\text { НАН та МОН України, Інсти- } \\
\text { тут кібернетики імені В.М. } \\
\text { Глушкова НАН України }\end{array}$ & $\begin{array}{l}\text { Сергієнко Іван } \\
\text { Васильович }\end{array}$ & $\begin{array}{c}123 \\
(0,008 \%)\end{array}$ \\
\hline
\end{tabular}

Примітка. * - у дужках зазначено напрямок у галузі інформатики (див. табл. 1).

** — відсоток загальної кількості звернень до БД.

\section{Анаміз публікаційної активності в галузі інформатики та комп'ютерної техніки}

Найбільша кількість публікацій у галузі інформаційних технологій стосується проблем, що пов'язані з апаратними рішеннями для перспективних засобів обчислювальної техніки, інформаційних і комунікаційних технологій. За останні 5 років кількість статей з цієї тематики становить, у середньому, понад 600 на місяць. Спостерігається приблизно лінійне збільшення кількості публікацій (від 40 до 50 на квартал). Значний приріст інформаційного масиву в цьому напрямку пов'язаний з наявністю наукових шкіл, творчих колективів, які плідно працюють над вирішенням актуальних проблем. Крім того, виникли види комп'ютерних технологгій, наприклад, комп'ютерне приладобудування, активно розвиваються комунікаційні технології.

У результаті аналізу публікаційної активності в галузі технологій і засобів із захисту інформації встановлено, що в цьому напрямку спостерігається найбільша, порівняно з іншими, швидкість зростання кількості публікацій, про що свідчать наведені на рис. 3 дані [12]. Така ситуація обумовлена актуальністю проблематики, складністю завдань і залученням все більшої кількості фахівців для розв'язування проблеми захисту інформації. Відображенням активного розвитку даної галузі інформаційних технологій є швидке зростання кількості наукових видань, поява фахових наукових журналів.

Висока динаміка публікаційної активності спостерігається в науковому напрямку, що пов'язаний з технологіями і засобами розробки програмних продуктів і систем (рис. 4) [13]. Адже в Україні існують активно працюючі наукові колективи в галузі програмування, розробки нових програмних продуктів користуються значним попитом.

Відображенням швидкого зростання електронних інформаційних ресурсів у світі, національних інформаційних ресурсів $\epsilon$ постійне швидке збільшення публікацій у напрямках: інтелектуальні інформаційні та інформаційно-аналітичні технології; інтегровані системи баз даних і знань; національні інформаційні ресурси. 


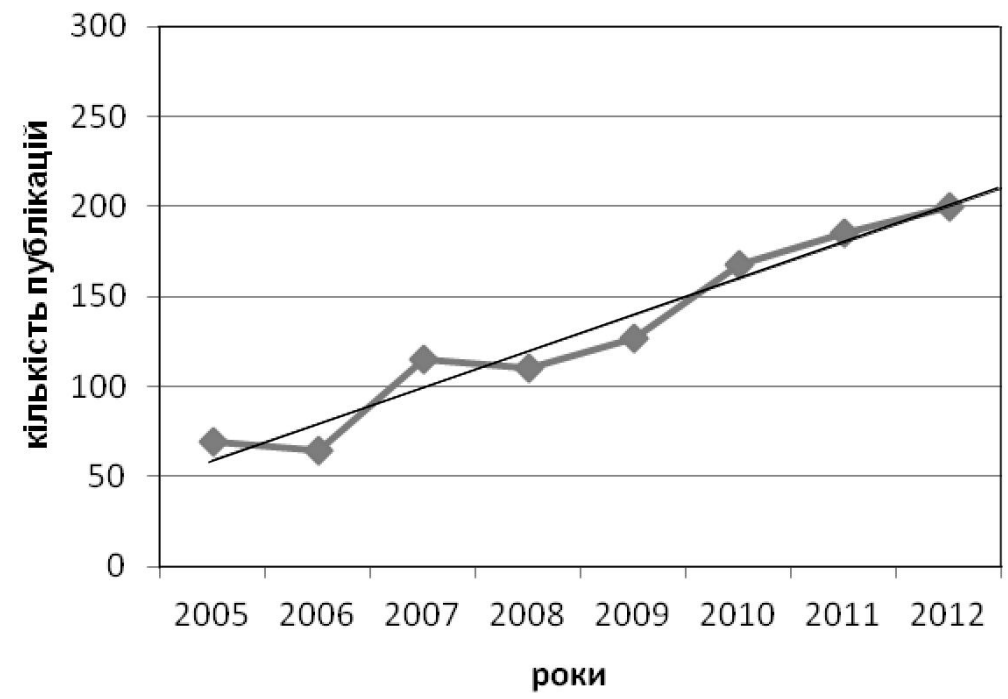

Рис. 3. Динаміка публікаційної активності в галузі технологій і засобів захисту інформації

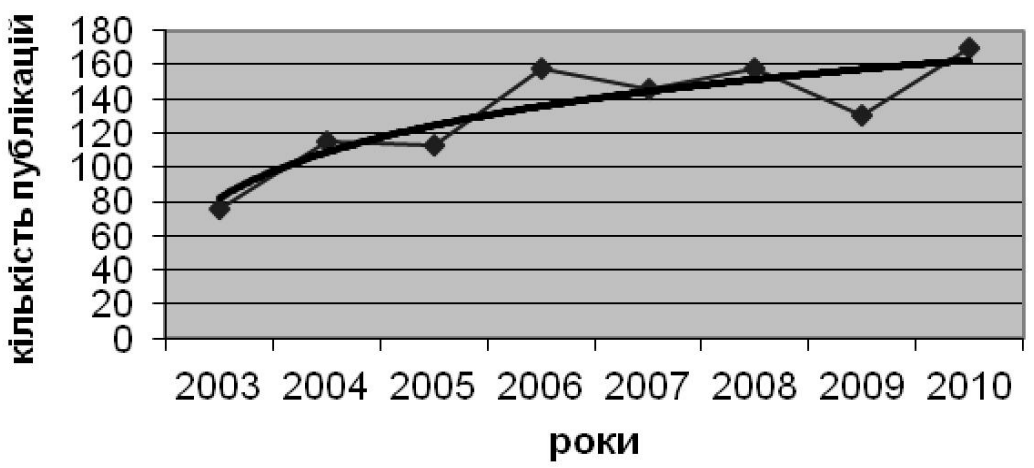

Рис. 4. Динаміка публікаційної активності в галузі розробки програмних продуктів

В Україні існують і активно працюють наукові школи в галузі технологій i засобів математичного моделювання, про що свідчить досить висока і постійно зростаюча кількість публікацій у галузі оптимізації і системного аналізу розв'язання надскладних завдань державного значення (рис. 5).

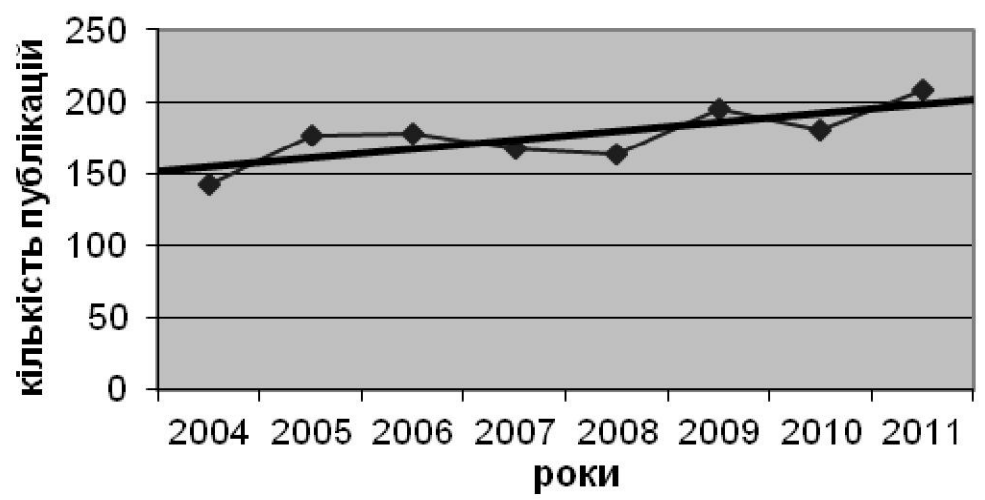

Рис. 5. Динаміка публікаційної активності у напрямку математичного моделювання і системного аналізу 
Приріст кількості публікацій у напрямках, що стосуються суперкомп'ютерних програмно-технічних засобів, телекомунікаційних мереж і систем, грід- і клаудтехнологій, а також технологій та інструментальних засобів електронного урядування, має позитивну динаміку. Про розвиток інформаційно-аналітичних систем, систем підтримки прийняття рішень свідчить збільшення записів у відповідних рубриках реферативної базі даних «Україніка наукова». У РБД представлена, як певна кількість оригінальних публікацій, так і велика кількість навчальної літератури й оглядових матеріалів з IT.

\section{Висновки}

1. Проведений аналіз показав, що більшість публікацій у галузі IT належать до пріоритетних напрямів у цій галузі.

2. Серед пріоритетних напрямків наукових досліджень у галузі інформаційних технологій найбільш швидко зростає кількість публікацій у напрямках: технології і засоби захисту інформації та телекомунікаційні мережі.

3. Необхідно відзначити, що значно більші можливості для проведення наукометричних досліджень створюються за спільного використання реферативних $\mathrm{i}$ повнотекстових баз даних періодичних видань, а також результатів вебометричного аналізу.

\section{Подяка}

Автори висловлюють глибоку вдячність всім співробітникам науково-технічного колективу Інституту проблем реєстрації інформації НАН України і Національної бібліотеки України імені В.І. Вернадського, які протягом багатьох років формують реферативну базу даних наукових видань України.

1. Рибачук В.П. Методологічні проблеми застосування наукометричного аналізу при прогнозуванні напрямків науково-технологічного прогресу / В.П. Рибачук // Наука та наукознавство. 2012. — № 1. - С. 36-45.

2. Зацман И.Н. Принципы обработки информационных ресурсов для оценки инновационного потенциала направлений научных исследований / Зацман И.Н., Шубников С.К. // Труды $9^{\text {ой }}$ Всероссийской научной конференции «Электронные библиотеки: перспективные методы и технологии, электронные коллекции» - RCDL’ 2007. - Переславль-Залесский (Россия). — 2007.

3. Климов Ю.Н. Современные информационные ресурсы - анализ закономерностей интегрального числа публикаций, моделирование и прогнозирование / Ю.Н. Климов // Оборонный комплекс - научно-техническому прогрессу России. — 2005. - № 4. - С. 12-24.

4. Климов Ю.Н. Системная методология исследования реальных потоков научно-технической информации в среде мирового информационного пространства: автореф. дис. на соискание степени докт. техн. наук: спец. 05.25.05 / Климов Юрий Николаевич. - М., 2009. — 48 с.

5. Науково-технічний потенціал у секторі ІКТ і його роль у розвитку світової і вітчизняної економіки / Т.К. Кваша, О.П. Кочеткова, Г.П. Задорожна [та ін.] // Науково-технічна інформація. - 2012. 一 № 1. - С. 3-9.

6. Заџман И.Н. Полидоменные модели электронных библиотек систем мониторинга сферы науки / Зацман И.Н. // Труды $8^{\text {ой }}$ Всероссийской научной конференции «Электронные библиотеки: 
перспективные методы и технологии, электронные коллекции» - RCDL' 2006. — Суздаль (Россия). -2006.

7. Радченко A.I. Видавнича діяльність Національної академії наук України: сучасний стан / А.І. Радченко // Звіти Науково-видавничої ради НАН України. - 2010. - С.1-7.

8. Крючин А.А. Медичні електронні ресурси України [Електронний ресурс] / А.А. Крючин, Н.В. Солоніна, Є.А. Крючина // Сучасні здобутки медичної інформатики: зб. матеріалів наук.практ. конф. з міжнародною участю (електронне видання), 13-14 червня 2013 року. - К.. НМАПО імені П.Л. Шупика, 2013. — С. 34-40. — 1 елект.. оп. диск (CD-ROM); 12 см.

9. Шарабчиев Ю.Т. Научные медицинские журналы Беларуси: какие они? / Ю.Т. Шарабчиев, О.С. Гук // Медицинские новости. - 2012. — № 3. - С. 11-18.

10. Аксентьева М.С. Особенности издания традиционного журнала в электронной и печатной форме. Проблемы и перспективы на примере опыта издания журнала «Успехи физических наук» [Электронный ресурс] / М.С. Аксентьева. - Режим доступа http://www.gpntb.ru/win/interevents/ crimea95/report/rep069_r.html.

11. Національна бібліотека України імені В.І. Вернадського. Електронний архів наукових періодичних видань України [Електронний ресурс]. — Режим доступу http://www.nbuv.gov.ua/

12. Крючин А.А. Наукометричні дослідження з напрямку «Захист інформації» за реферативною базою даних «Україніка наукова» / А.А. Крючин, С.В. Добровська, І.В. Балагура // Информационные технологии и безопасность: оценка состояния. — 2013. - Вип. 13. - С. 87-94.

13. Кириленко С.E. Інформаційні ресурси реферативної БД «Україніка наукова» 3 математикного моделювання та системного аналізу // Реєстрація, зберігання і оброб. даних: зб. наук. праць за матеріалами Щорічної підсумкової наукової конференції 27-28 лютого 2013 року / НАН України. Інститут проблем реєстрації інформації; відпов. ред. В.В.Петров. - К.: ІПРІ НАН України, 2013. - 258 c. — ISBN 978-966-02-6842-5. 